\title{
Shrine Traditions of Wakhan Afghanistan
}

\author{
John Mock ${ }^{1}$ \\ University of California, Santa Cruz (retired)
}

\begin{abstract}
This study, based on field work from 2004 to 2010, describes the religious, social and historical context of shrines in Wakhan District of Badakhshan Province, Afghanistan. Scholarly analysis of the significance of the shrines is balanced with the perspective of the people of Wakhan for whom the shrine traditions are part of a living landscape. Translated excerpts from interviews conducted in the Wakhi language at the shrines bring the Wakhi voice to the study, which focuses on one shrine (the shrine of the miracle of Nāser Khosrow in Yimit village) as an exemplar of shrine traditions. The study draws comparisons between documented shrine traditions in adjacent Wakhan Tajikistan and in Hunza-Gojal of Pakistan, locates the traditions within Pamir Isma ilism, and suggests outlines of a broader Pamir interpretive community.
\end{abstract}

\section{Keywords}

Wakhan, Afghanistan, Pamir, Isma ílism, saints, shrines, religion

The people of Wakhan consider all Wakhan as a ring and Khandut as its nagina ("jewel").

Religious scholar Gholām 'Ali of Qāzideh

It is generally accepted that the development of Pamir Isma ilism involved the absorption of local customs and traditions (Dodykhudoeva, 151; Iloliev 2008 b , 64). From the perspective of a cultural focal area, it may equally be said that the culture of Wakhan (Vakhān) and the Pamir assimilated Isma ili and Sufi concepts as it had assimilated previous concepts and traditions. In effect, the Pamir and, of particular emphasis for this paper, Wakhan are a sort of

\footnotetext{
1 Support for research in Afghanistan and Tajikistan was provided by a grant from the Christensen Fund of Palo Alto, California. Additional support was through a Fulbright Senior Scholar Award for Pakistan and a Fulbright Regional Travel Grant for Tajikistan. The American Institute of Pakistan Studies provided facilities in Islamabad. Consulting work with the Wildlife Conservation Society's USAID-funded Afghanistan Biodiversity Project and with the Aga Khan Foundation-Afghanistan and GTZ of Germany enabled me to identify many of the shrines and sites. My thanks to Mr. Fazal Amin Beg, M.Phil., who worked with me on collection, transcription and translation of the Wakhi language material.
} 
cultural palimpsest, a recipient of a complex series of influences. The process, however, should not be viewed as unidirectional. ${ }^{2}$ Rather, Wakhan and the Pamir participate in an ethno-linguistic area that is also an interpretive area, where neighboring communities share significant features of meaning that transcend linguistic and cultural boundaries. ${ }^{3}$ The diachronous threads of history and tradition weave together with the synchronous threads of interpersonal and intercommunity relations to form the broader social fabric of the region, in which the predominant interpretive mode today is that of Isma ili and Sufi thought, in a distinctive form that is called Pamir Isma ilism.

\section{Historical and Cultural Threads}

For more than a thousand years, a fairly steady stream of merchants, monks, travelers, and occasionally armies passed through Wakhan along the so-called Silk Road ${ }^{4}$ from at least the first century BCE (Franck, 2; Zelinksky, 54). The religious traditions that came with these travelers include Zoroastrianism (from Samarkand and Sogdiana to the north and west), Buddhism (from Balur just to the south, Kabul and Balkh to the west, and Khotan to the east), Manichaeism, and Nestorianism (both from the west via Sogdiana). ${ }^{5}$

Numerous rock carvings demonstrate a human presence in Wakhan from the prehistoric Bronze Age, when wild yaks were hunted by mounted bowmen on the Pamir, to the first millennium CE (Hauptmann, 24-28; Middleton and Thomas, 600-06; Mock and O'Neil 2005, 13; Miller, 54-59; Naumann 1973, 252). Many of the rock carvings depict wild game animals and hunters, and may have been part of ceremonial or ritual practices (Hauptmann, 25). Rock carvings of wild goats in the Scythian animal style can be associated with seventh century BCE Saka people resident in the Pamir (Litvinsky, 148). Whatever the original cultural relevance of these rock carvings, it is unknown to today's inhabitants, who have told me that the rock carvings were "made by fereshta (angel[s])."

\footnotetext{
2 The dialogical process of incorporation of indigenous tradition into Islamic discourse and nativization of outside (Islamic) tradition into indigenous discourse is a well-known Central Asia phenomenon. See DeWeese 1994, 445-46.

${ }^{3}$ Shared features of the Pamir, Dardic, and Nuristani languages define a Pamir-Hindukush ethnolinguistic region (Payne 1989, 420-23) that is a transitional zone between South Asia and Central Asia (Tikkanen 1995).

${ }^{4}$ This trade route was termed die Seidenstrasse by Baron Ferdinand von Richtofen in the nineteenth century, although Chinese silk had been traded along the route from its inception.

${ }^{5}$ The scholarly essays in Whitfield 2004 elucidate the historical currents generated by trade, travel, war, and religion on the Silk Road.
} 
People speaking Eastern Iranian languages have lived in the vicinity of the upper Amu Darya since at least the seventh century BCE and the Pamiri languages, ${ }^{6}$ most notably Wakhi, are their closest living descendants (Bailey, 68; Payne 1996, 367; Skjærvø, 370). The Wakhi language (or more accurately 'pre-Wakhi') was in close contact with Indic languages from very ancient times when Indic and Iranian were mutually intelligible. Wakhi has continued fairly intensive interaction with the neighboring northwestern Indic language, Khowar, up to the present (Bashir 2001, 3; Morgenstierne, 441-42).

It appears that Wakhan or wukh watan is the homeland of Wakhi or wakhikwor-speaking Wakhik people, as evidenced by the shared onomastics of the toponym, ${ }^{7}$ the ethnonym and the language (Bashir 2009, 825), and that the people were part of the initial wave of Iranian settlers in the Pamir (Morgenstierne, 435). Wakhi and the modern Pamiri languages are unwritten languages. Although there is ample evidence of their long presence in the Pamir, they are not attested through texts, in contrast to their historical Eastern Iranian relatives.

Written references to Wakhan as a kingdom are found not only in the eighth century CE Tang dynasty annals, but in the ninth century $A k b b \bar{a} r$ Makka ${ }^{8}$ the tenth-century Hodud al-'Alam, ${ }^{9}$ and in the thirteenth century writings of Marco Polo. ${ }^{10}$ These references all use the toponym Wakhan, underscoring the continuity of the language in its place.

By the end of the first century CE, China's Han Dynasty was the predominant Silk Road power as far east as the Pamir, although the majority of that eastern population was not Chinese (Groussett, 41-42). Tibet emerged as a

\footnotetext{
${ }^{6}$ None of the modern Pamiri languages spoken today are direct descendants of the historic Eastern Iranian languages (although the neighboring Yaghnobi is a descendant of Sogdian). The Khotanese, Khwarazmian, and Sogdian languages are attested from texts, but these languages have died out (Bashir 2009, 857; Edelman and Dodykhudoeva, 776; Payne 1989, 422).

7 The earliest confirmation of the toponym is in China's Tang dynasty annals, which record interaction of the Tang court with the Kingdom of Wakhan in 720 and 742 CE, and a battle between Chinese and Tibetan forces in Wakhan in 747 CE. The Tang annals transcribe the name of Wakhan as Hu-k'an, and Beckwith (133 fn) notes that $H u$ would have been pronounced as $/ \gamma$ wak/ in Central Asia. This would give a pronunciation of $/ \gamma$ wak-kan/, remarkably close to today's pronunciation.

${ }^{8}$ Al-Azraqi chronicles that the armies of the Caliph al-Ma'mun, under the authority of his viceroy for the east, Fazl b. Sahl, campaigned against the Kābolshāh and the Qaghan of Tibet, and defeated Wakhan around 814-15 CE (Beckwith, 160-62).

9 Wakhan is mentioned as a region with "Sikashim (Ishkāshim)" as its "chief place." Khandut (Khamdādh) is described as the location of the "idol-temples (but-khāna-hā) of the Wakhis," and "on its left side is a fortress occupied by Tibetans" (Minorsky, 121).

${ }^{10}$ Polo evidently passed through Wakhan around 1273. He mentions "Vokhan... [where] the people worship Mahommet, and have a peculiar language" (Polo, 162).
} 
major power in the seventh century CE and between 650 and $850 \mathrm{CE}$ China and Tibet vied for control of the kingdom of Wakhan and of the trade route through it (Beckwith, 89-91, 123, 132-33; Stein 1922, 115-16). The Chinese Buddhist monk Xuanzang passed through Wakhan some time shortly after $640 \mathrm{CE}$ on his return from India. He mentioned the village of Khandut as the capital of Wakhan and described a Buddhist vihara in the center of the town (Stein 1981, 866). ${ }^{11}$ This corroborates the description given in Hodud al-'Älam of Khandut (Khamdādh) as the location of the vihara ("idol-temples") of the Wakhis with a separate Tibetan fort nearby (Minorsky, 121) and indicates that the vihara was not for the Tibetans (or the Chinese, or other religious travelers alone), but was part of the religious life of the indigenous (Wakhi) population. Numerous old forts (qal'a) in both Tajikistan and Afghanistan Wakhan, such as the fort at Panja and the forts associated with the Kafir king QaQa, date from this era or perhaps even earlier (Iloliev 2008b, 65; Miller, 37-43). The $\mathrm{QaQa}^{12}$ forts are linked into the present religious fabric not as shrines or the locus of religious practice, but rather through the ascription of the defeat of the Kafir king by 'Ali, the forth caliph succeeding the prophet of Islam. Although the army of the Caliph al-Ma'mun campaigned against the Qaghan of Tibet and defeated Wakhan around 814-15, it is historically impossible that 'Ali should have been physically involved in the campaign. These forts are located in Qāzideh and Korkut in Afghanistan and in Namadgut in Tajikistan, with additional secondary locations associated with the daughters and the general(s) of QaQa. The large fort in Qāzideh is recorded as being last occupied in the late nineteenth century (Miller, 39). The Kansir fort at Korkut dates to the eighth or ninth century and figures prominently in the battle between Chinese and Tibetan forces in 747 (Miller, 43; Mock 2008; Stein 1907, 9) (Figure 1). The Tibetans appear to have reasserted their authority in Wakhan shortly after their defeat in this battle, but by the end of the ninth century the high water mark of Buddhism in the Hindukush and Pamir had receded, the Tibetan empire no longer reached to Wakhan, and the region was increasingly influenced by Islam (Beckwith, 172; Hauptmann, 32).

\footnotetext{
${ }^{11}$ Stein, like Wood and Olufsen before him, did not visit Khandut and the villages on the true left (southern) bank of the Panj River. Hence, Stein never actually saw the vihara, nor have any subsequent travelers described it.

${ }_{12}$ The legend of Qa Qa-e jodu and his fort at Hissar near Dushanbe is well known in Tajikistan (Middleton and Thomas, 122). The legends of QaQa in Wakhan are less well known, but equally of interest. Conjecture as to any historical identity for QaQa has yet to appear in scholarly work.
} 


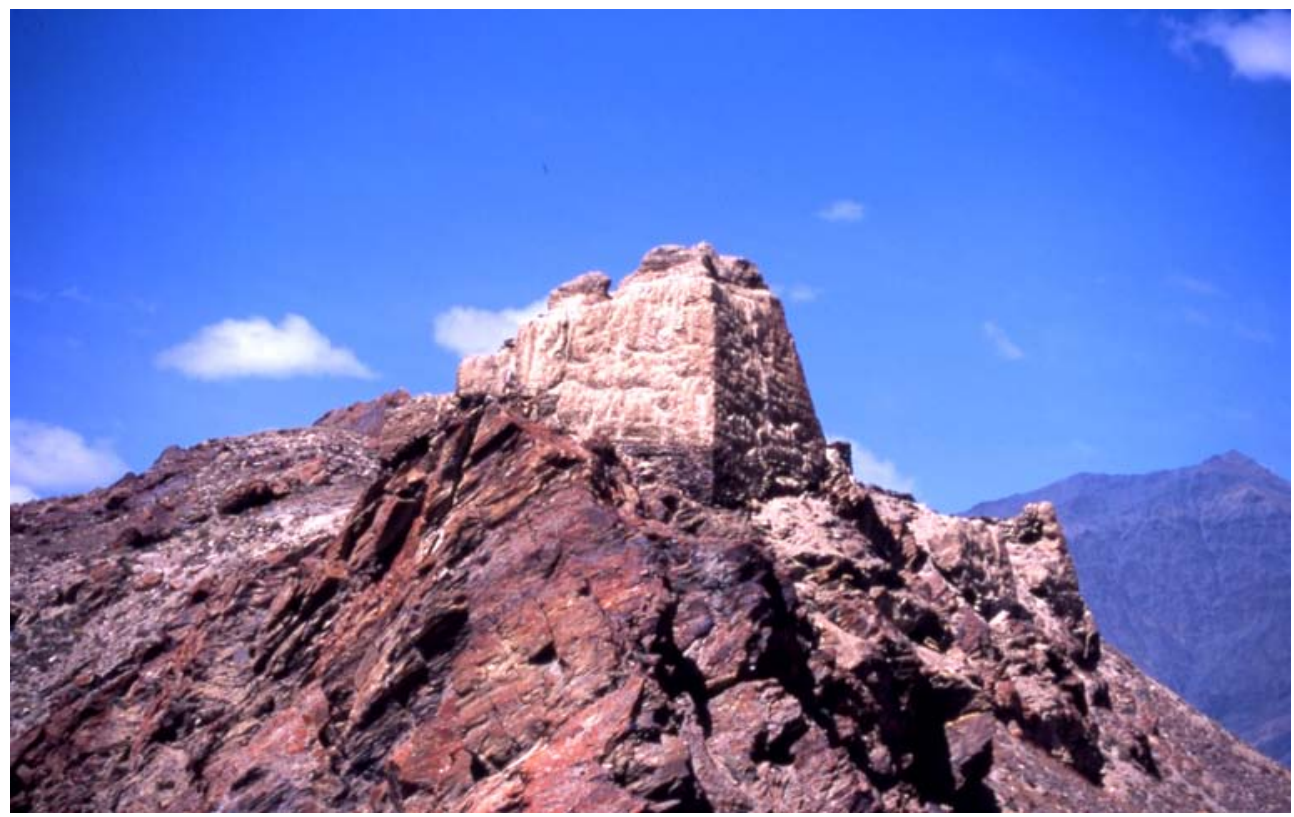

Fig. 1. Kansir Fort above Korkut village

Isma ili missionaries were active in Samarkand and Bukhara, where the Isma ili message found acceptance at the Samanid court in the beginning of the tenth century (Stern, 79). Subsequent opposite reaction in Bukhara and from neighboring states induced a relocation of the Isma ili message into the Pamir region (Iloliev 2008a, 28). There, Isma ili teaching encountered the earlier magus and shaman traditions. Isma ilism was clearly present in the region when Nāser Khosrow (Nasir Khusraw) came to Badakhshan at the invitation of a local Ismaili ruler (Schadl, 72), but the Isma ili community today universally regards Nāser Khosrow as the founding figure.

\section{Wakhan Shrine Traditions}

Wakhan is home to numerous shrines. Abdulmamad Iloliev, in his study of saints and shrines of Wakhan in Tajikistan, notes, "there are at least two or more shrines in almost every village of Wakhan" (Iloliev 2008b, 64), which is equally true for Afghanistan Wakhan. Indeed, taken as a whole, all of Wakhan would appear to match Ghulam Ali's description of a ring (nagina), or as 
Iloliev phrases the local description of Wakhan, "the stepping place of the pirs" (qadamgāh-e pirān).

Iloliev describes three types of shrines in Tajikistan Wakhan; oston (standard Persian ästān "threshold"), qadamgoh (i.e. qadamgāh "stepping place"), and mazar (i.e. mazār "tomb"). Oston in Afghanistan Wakhan are typically trees, often decorated with colored strips of cloth, or a collection of stones with unique shape, color, or markings. Qadamgohs are places where saints reputedly visited. A rock with the mark of a footprint or the impression of a staff (osoyi) apparent on it may mark such sites, or a grove of trees or a spring may mark the site of a saint's visitation. Mazars are typically burial places of a saint. Shrines where trees are not present often have numerous sticks, with colored cloth strips tied to them, placed around them. The horns of wild ungulates (ibex and urial) are also frequently placed at shrine sites. ${ }^{13}$

Iloliev further describes three types of saint: the well-known saints of Shi i and Sufi tradition; the travelers and dervishes significant mostly to Pamir Isma ili tradition; and local pirs and great men or buzurgwor (i.e. bozorg(a)vār) (Iloliev 2008b, 63-64). Shrines of Shi i and Sufi saints tend to be either oston or qadamgoh. Shrines of travelers and dervishes tend to be qadamgoh. Shrines of local pirs and buzurgwor tend to be mazar. ${ }^{14}$ Not infrequently, dervish travelers and local pirs or buzurgwor have a mazar shrine in Wakhan along with several qadamgoh shrines, such as Shah Qambar-e Aftob (Āftāb), whose mazar is in Langar village in Tajikistan Wakhan, but who has qadamgoh shrines in Afghanistan Wakhan. Khoja Big Ali and Khoja Maribor, local pirs, have qadamgoh in Sost village of Sarhadd-e Brughel but mazar in Langar, both in Afghanistan Wakhan.

Following Iloliev's typology, the shrines and village locations (given in parentheses) of Afghanistan Wakhan are shown below.

13 Ibex and urial live in almost all of the side valleys of the Wakhi settlement area of Afghanistan Wakhan. Argali sheep live in the Pamir above the elevation of Wakhi settlements. Argali horns occasionally decorate shrines, but are heavy and must be brought from some distance. The concept of wild ungulates as "pure" creatures associated with the spiritual world is widespread throughout the Pamir-Hindukush region. See Mock 1998, 45-46.

${ }_{14}$ Hopkins describes a similar typology of religious authorities in the Pakistan-Afghanistan frontier region, distinguishing men of religious learning who were charismatic outsiders and indigenous religious dignitaries (Hopkins, 1462-63). 


\begin{tabular}{|c|c|c|c|}
\hline \multirow[t]{2}{*}{ Shrines } & \multicolumn{3}{|c|}{ Saints } \\
\hline & Shici and Sufi & $\begin{array}{c}\text { Travelers and } \\
\text { dervishes }\end{array}$ & $\begin{array}{l}\text { Local pirs and } \\
\text { buzurgwors }\end{array}$ \\
\hline oston (āstān) & $\begin{array}{l}\text { Gisu-e Hazrat } \\
\text { Muhammad } \\
\text { (Qāzideh) Shoh } \\
\text { Mubarak Mard-e } \\
\text { Wali (Shkharv) } \\
\text { Chiltan (Paghish) } \\
\text { Hajat Murod } \\
\text { (Paghish) Poy-e } \\
\text { Duldul (Khandut) } \\
\text { Savz Pushon } \\
\text { (Pekuy) Panja Shoh } \\
\text { (Pinja) Bi Fotima } \\
\text { (Gozkhun) Shoh-e } \\
\text { Vilayat (Wardif) } \\
\text { Khoja-e Khizer } \\
\text { (Brughel) }\end{array}$ & $\begin{array}{l}\text { Ziarat-e Shams } \\
\text { (Kuzget) }\end{array}$ & \\
\hline mazar (mazār) & $\begin{array}{l}\text { Chihel Dukhtaron } \\
\text { (Shkharv) Panja-e } \\
\text { Shoh (Khandut) }\end{array}$ & & $\begin{array}{l}\text { Mir Khuja Aziz } \\
\text { (Putr) Alus } \\
\text { Malak-Fatah Ali } \\
\text { Shoh (Khandut) } \\
\text { Khoja Big Ali } \\
\text { (Langar) Khoja } \\
\text { Maribor (Langar) }\end{array}$ \\
\hline $\begin{array}{l}\text { qadamgoh } \\
\text { (qadamgāh) }\end{array}$ & $\begin{array}{l}\text { Shoh-e Najaf (Putr) } \\
\text { Pir-e Guliston } \\
\text { (Putr) Khoja-e } \\
\text { Khizer (Sast) } \\
\text { Mard-e Wali Savz } \\
\text { Pushon (Yizik) } \\
\text { Qadamgoh-e Ali } \\
\text { (Ali Su, Pamir-e } \\
\text { Bozorg) }\end{array}$ & $\begin{array}{l}\text { Shoh-e Odil } \\
\text { (Qāzideh) Nasiri } \\
\text { Khusraw (Yimit) } \\
\text { Khoja-e Rabon } \\
\text { (Yimit) Shoh-e } \\
\text { Obod (Yimit) } \\
\text { Shohbozi Buland } \\
\text { Parwoz (Yimit) } \\
\text { Ziarat-e Shoh } \\
\text { Qambar } \\
\text { (Gozkhun) } \\
\text { Chiroghdon-e } \\
\text { Shoh Qambar-e } \\
\text { Aftob (Rurung) }\end{array}$ & $\begin{array}{l}\text { Khoja Shams } \\
\text { (Qāzideh) Khoja } \\
\text { Sheikh (Khandut) } \\
\text { Khoja Maribor } \\
\text { (Sost, Sarhadd-e } \\
\text { Brughel) Khoja } \\
\text { Big Ali (Sost, } \\
\text { Sarhadd-e } \\
\text { Brughel) }\end{array}$ \\
\hline
\end{tabular}


At shrines in Afghanistan Wakhan, one immediately notices that, unlike shrines in Tajikistan Wakhan where a process of "museumization" is the recent trend (Iloliev 2008b, 68), there is little sense of museumization. Rather, there is a sense of concealing the shrine traditions. This can be associated with taqiya practices among the Badakhshan Isma ili community and longstanding concern over hostility and discrimination by other sects of Islam (Dupree, 16; Emadi, 110-14; Schadl, 73). One corollary of such attitudes is a reported wave of looting of cultural sites during the mujahiddin period (Mock 2007). The overall fragility of cultural sites, including shrines, historic monuments and prehistoric rock carvings, is of concern given the increase of visitors, both foreign tourists and Afghan traders, since 2001 (Mock and O'Neil, 14).

At each shrine, one notices a specific place where oil or clarified butter is applied. If there is a depression in the rock, a wick may be placed in the oil/ butter and the shrine illuminated, or open oil lamps may be placed at the spot. As Iloliev notes, "shrines were constructed by believers in order to have a more direct contact with supernatural powers at the places where the saints were buried or were believed to have performed some kind of miracle... and to receive spiritual blessing (barakat) from them" (Iloliev 2008a, 46). Such places where the relationship with the sacred could be mediated were likely part of the indigenous belief system prior to the coming of Islam. Shrine sites are the locus for integration and assimilation of indigenous beliefs into Islamic discourse and for reaffirming and mobilizing a shared sense of the sacred in the landscape.

\section{Oston (Āstān) Shrines}

The oston of Panja Shah in Qila-e Panja is an example of this category of shrine in Afghanistan Wakhan. According to the family of Nasir al-Din Shah, the great grandson of Mir Fāteh 'Ali Shah and grandson of Mir Sarboland Shah, the shrine and panja stone were once located at the Qila-e Panja (i.e., qal'a "fort"), but were moved sometime after the end of the Mirdom of Wakhan. ${ }^{15}$ A small shrine can still be found at the fort (Miller, 41), but the oston where offerings are made is now located near to the home of Nasir al-Din Shah. This small oston is decorated with some strips of colored cloth on sticks and has a stone with a hole in it that serves as the spot where offerings are placed. Nasir

${ }^{15}$ The last mir of Wakhan, 'Ali Marda'n Shah, elder son of Fāteh 'Ali Shah, fled Wakhan along with many of his subjects in 1883 . He had hosted Russian explorers and feared retribution from Kabul. In 1886, when the British Colonel Lockhart visited Wakhan, he found it under the rule of Kabul, with Gaffār Khan Kirghiz serving as governor (Alder, 193-95). 
al-Din's son, Zalmay, said to the author of this article that the shrine needed to be in a less public and more protected place. The panja stone, which has five smooth and parallel finger-like grooves in it, is kept at Nasir al-Din's home (figs. 2 and 3). In Shi i Islam, the number five signifies the Five Pure Persons: the Prophet Mohammad, his daughter Fatima, his son-in-law 'Ali, and his grandsons Hasan and Hosayn. In the Pamir, the Shi i traditions blended with Sufi and Isma ili thought to form a unique Pamir Isma ili belief and practice called Panj-tani, "five bodies" (Iloliev 2008a, 41), often symbolized by a handprint. The stone carries the same significance for today's community, but, as Zalmay stated to the author, may well pre-date the introduction of Islam in the Pamir. Its unique size and shape may have been significant for earlier beliefs. ${ }^{16}$ The religious leader of Panja, Pir Shah Esmāi il, described the tradition surrounding this stone: ${ }^{17}$

The name of this village was Panja-e muborak (mobārak "auspicious") and not Qala-e Panja. Its earliest name is Panja-e muborak, because here is a shrine. In the middle of our mountain, there is a stone. On this stone, Hazrat 'Ali [...], King of men, is said to have offered prayers. The signs of his five fingers, shin, and his staff, these signs still exist. From that point, he has then rolled down/thrown a stone towards this village. The stone is like a lump, small. The five fingers of Shoh-e muborak (Shāh-e mobārak) are imprinted there on the stone. The stone has come down on top of the fort. God knows, however, if the stone has come down on the top of the fort or not. But we should not tell a lie to you. Who brought the stone to the top of the fort and where was it placed, etc.? That stone is still present. Afterwards, this name, as I described earlier, whether any infidel or someone else, I don't know that, has changed it. Afterwards, this fort was constructed here in the name of Panja-e muborak, and then they called it Qala-e Panja.

The jamat khana ${ }^{18}$ of Khandut is located in the center of the village. Khandut is one of the oldest settlements in Afghanistan Wakhan, and is presently the district headquarters. Khandut is known from historical records as the location of a large Buddhist vihara, whose location has never been identified in modern scholarship. Next to the jamat khana and built into the wall

\footnotetext{
16 The shrine Panja Shah in Chapursan Valley, a Wakhi population area in northern Pakistan that is linked to Wakhan via a pass, has a stone with five claw or finger marks, on which libations of clarified butter are offered. Similar rock marking shrines in Chapursan led Aurel Stein, who visited Chapursan in 1913, to remark on their resemblance to Buddhist rock shrines as "a case of continuity of local worship reaching back to pre-Muhammadan times" (Stein 1981, 52; Mock 1998, 308).

17 This and all other narratives in this article are translated from the Wakhi language interviews recorded during fieldwork in Wakhan in 2007.

18 Jamat khana, (Pers. jamäa $a t-k h \bar{a} n a$ ) the Isma ili house of prayer, study, and community.
} 


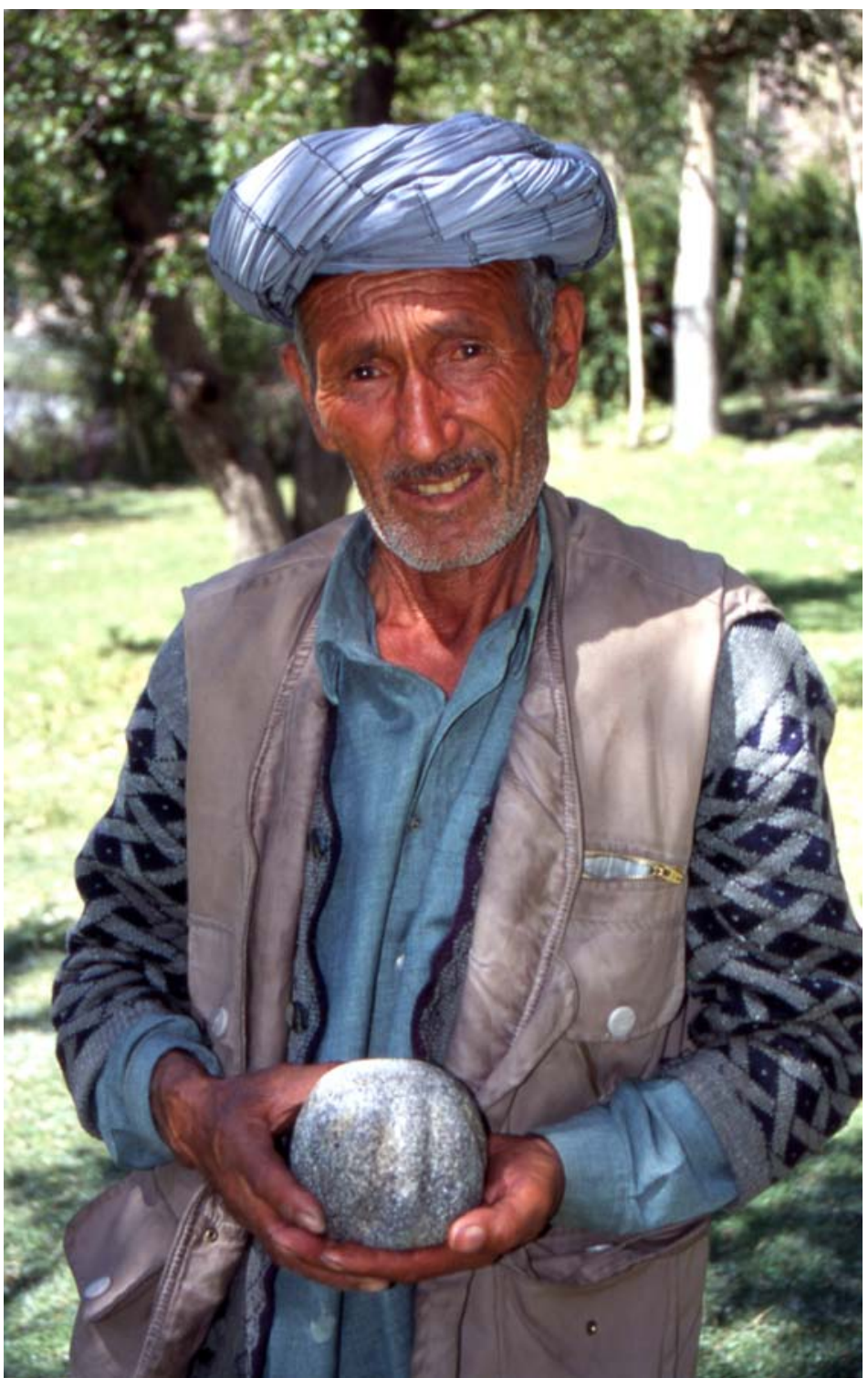

Fig. 2. Nasir al-Din Shah holding the Panja stone 


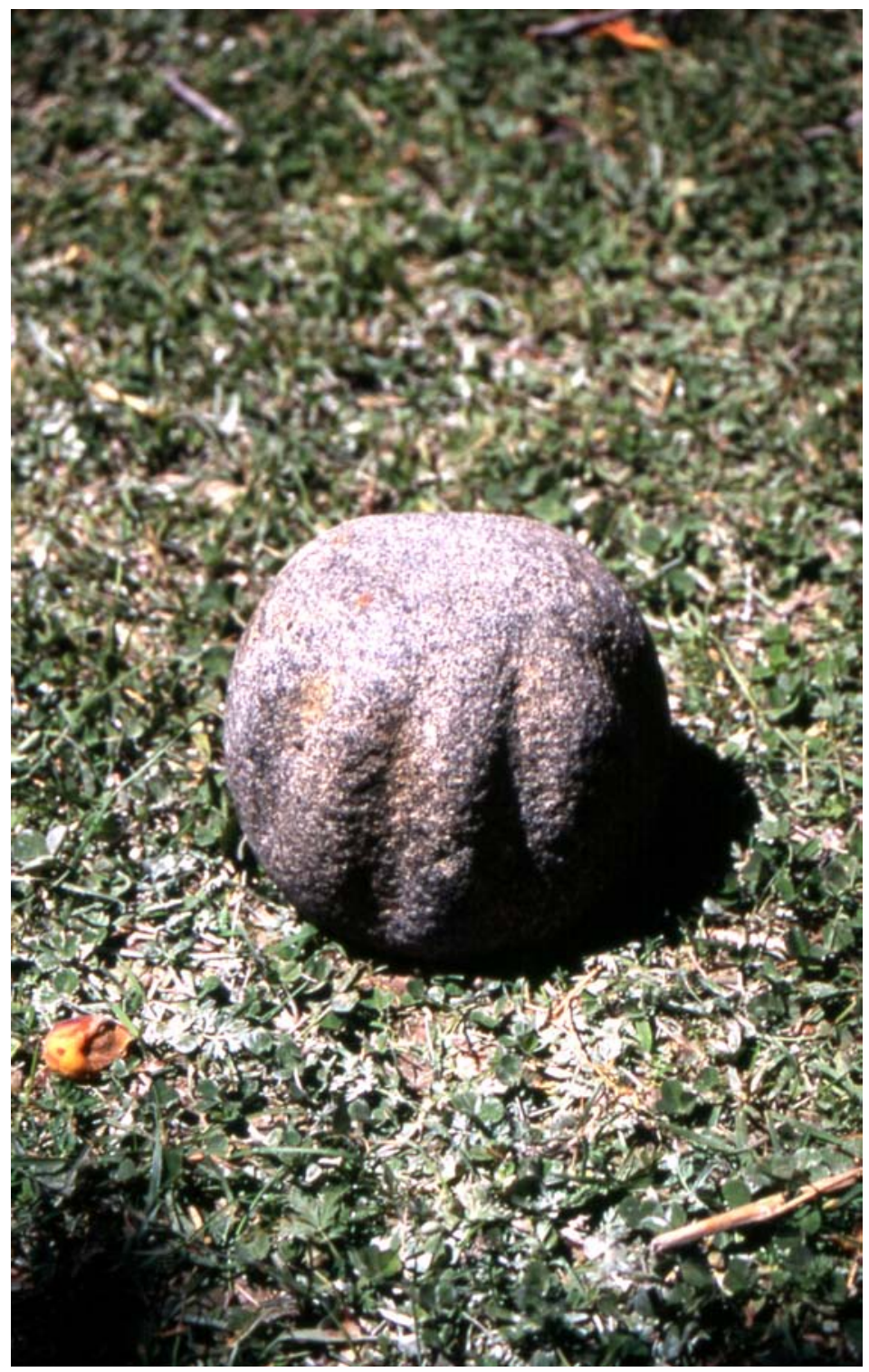

Fig. 3. The Panja stone of Qila-e Panja 
surrounding it is a small oston with several unique stones, some flags on sticks and wild ungulate horns, all located next to a large tree. The oston receives oil or butter, as indicated by the oiled appearance of the small stones. In this respect, it is similar to other shrines. However, an opening in the wall leads into a dilapidated circular structure made of sun-dried bricks, neatly arranged to form a larger base circle with an upper, smaller circle. The shape of this now-ruined structure is reminiscent of old Buddhist vihara found in India, and the sun dried bricks are seemingly identical with the bricks used in construction of the Kansir fort at Korkut, which dates to the eighth or ninth century CE. Could it be that these are the remains of the famous vihara of Khandut? Without additional archaeological study and perhaps radiocarbon dating, it must remain as speculation. However, we might assume that the location has long been linked with the sacred and that the oston most likely predates the jamat khana, demonstrating a continuation of religious practice in this location (Figure 4). ${ }^{19}$

\section{Mazar Shrines}

Actual mazars - that is, burial shrines - are the least common type of shrine in Wakhan. Two are burial places of mirs, and one mazar is the burial place of two local miracle-workers, Khoja Big Ali (Khwāja Beg 'Ali) and Khoja Maribor. Their mazar is at Langar, the highest elevation area that Wakhi people have cultivated. Langar is located along the upper Wakhan River, about two days' walk above the highest permanent settlements at Sarhadd-e Brughel. There is a small house at Langar used by herders going to and from the Little Pamir. ${ }^{20}$ A broken irrigation canal leading to a now untended field shows that cultivation (probably barley) once took place.

The rectangular earthen mazar is located on top of a ridge. It is decorated with poles on which are tied strips of colored cloth, with ibex horns and piles of small stones. A small, somewhat dilapidated mosque structure is next to the mazar. Along the ridge are other graves. Some graves are inside low rectangular mud walls with no roof, a style common throughout the Wakhi settlement area. There are no domed graves, which are typical of Kyrgyz burials in the Pamir. Wakhi people state that any Wakhi person who dies on the Little Pamir

19 The establishment of an Islamic shrine at the place of a Buddhist shrine is attested from Thol in Nager (Hunza Valley) in northern Pakistan, which is on the ancient route from Gilgit via Hunza to Wakhan (Frembgen, 75; Stein 1907, 20).

${ }^{20}$ The Little Pamir (Wakhi Wuch Pamir, Pers. Pāmīr-e khord) is the high elevation U-shaped valley about $100 \mathrm{~km}$ long and $10 \mathrm{~km}$ wide at the eastern end of Wakhan. 


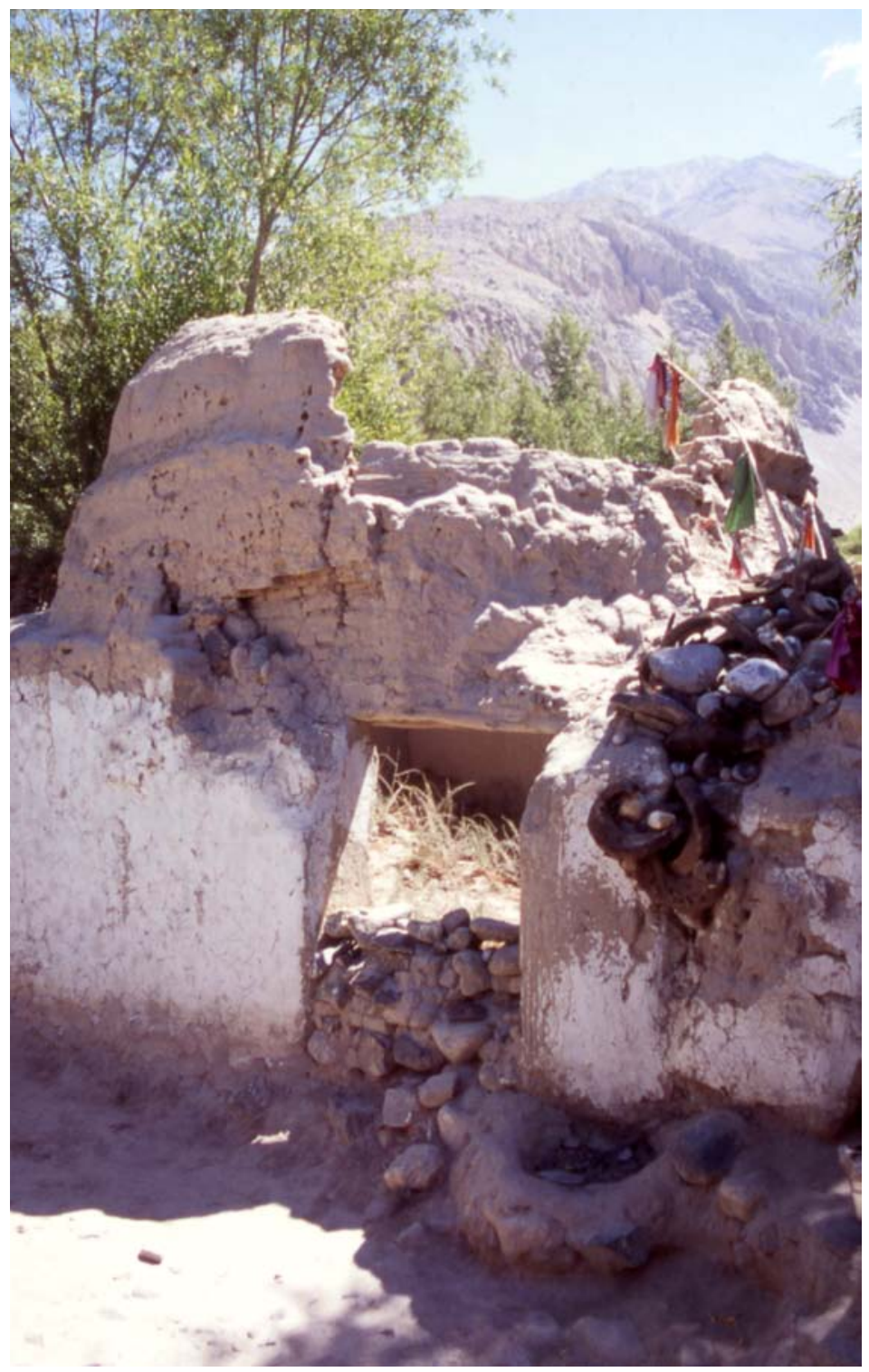

Fig. 4. Khandut oston at Jamat Khana 
is not and cannot be buried on the Pamir. Instead, the body is brought to Langar for burial.

The mazar is the burial place of Khoja Big Ali. His brother, Khoja Maribor, is also said to be buried there. The Khoja clan of Wakhan are the religious leaders of the Isma ili community. They claim descent from Sayyed Sohrāb-e Vali, a fifteenth-century Isma ili missionary of the Alamut tradition (Iloliev 2008a, 34). There is a local tradition that the Sayyed was a companion of Nāser Khosrow, although this genealogy cannot be verified, and, from the date of 1453 of Sayyed Sohrāb-e Vali's work "Thirty-six pages," it seems that the two Isma ili missionaries were not actual historical contemporaries (Ivanov, 93, cited in Iloliev 2008a, 49). Nevertheless, the Khoja clan claims Sayyed Sohrāb-e Vali came from Yamgān, where Nāser Khosrow lived. ${ }^{21}$

Khoja Big Ali and Khoja Maribor resided in Sost village, in the upper Wakhi settlement area of Sarhadd-e Brughel. There they met Khizer (Khezr), the mysterious saint guide, who caused a hot spring to emerge. After meeting him, they performed miracles. Subsequently, they went to Langar and displayed more miracles. Khoja Big Ali and Khoja Maribor have qadamgoh shrines, but their mazar in Langar is the main shrine.

The current resident of the house in Sost where the brothers performed miracles gave this narrative:

Sost is the highest of all the settlements in Wakhan. There are springs here, hot baths (hammām) are here. That spring here is Hazarti (Hazrat-e) Khoja Big Ali's. Hazrat Khoja Big Ali has actually seen the sight (didor, Pers. didār) here. He has seen Hazrat Khizer here. In the house where I live, that is Hazrat Khoja Big Ali's. About that house, the story is like this. Khoja Big Ali and Khoja Maribor were brothers here in Sost. They too were people of this soil like us. They did some communal work here, for many people like this, as this brother is preparing food here. They prepared $b a t,{ }^{22}$ the bat of our old heritage. Then the people had eaten and for him they left some in a small bowl (pil), like this. He was a bit lame of foot.

${ }^{21}$ The historical traditions of the Khoja clan are found in a book titled Gowhar-riz. Iloliev examined two versions of this manuscript held in private collections in Tajikistan, one in Shughnan and the other in Yamg village of Eshkāshm (Ishkashim) District (Iloliev 2008a, 11-14). I heard reference to the book in Wakhan, but did not see it. Iloliev notes that a copy is held at the Institute of Ismaili Studies Library in London, of which Qudratbeg Elchibekov, from the Institute of Oriental Studies and Written Heritage in Dushanbe, is preparing a translation (Jo-Ann Gross, personal communication). Khoja clan members in Wakhan stated there is also a copy in northern Pakistan, most likely held by one of the religious leaders there who also claims descent from Sayyed Sohrāb-e Vali.

${ }^{22}$ Bat is wheat flour cooked in butter and water, with meat often added. It is served on ceremonial occasions, cooked in a large cauldron to feed many. 
He said, "Hey brother! This wood beam doesn't reach; I must go to Sarhadd in order to borrow a beam. This beam doesn't reach to other side so I'll add to it." Khoja Big Ali said so to his brother Khoja Maribor. He said, "Okay, go." The others ate the food and left some for him in a small bowl ( $p i l$ ). When he reaches this spring, Hazrat Khizer comes from the other side, and he recognizes him. Khoja Maribor goes, and Khoja Big Ali encounters him. As grandpa Gulbast used to tell us, they were brothers. That is, he went to the spring, o dear! Thus, he recognizes Hazrat Khizer. After recognizing him, he gets down from the donkey. Hazrat Khizer asks, "O Khoja Big Ali! Where are you going?" He replies, "Your honor! I constructed a house, but the beam was short." Hazrat Khizer says, "Over there near your donkey's foot, water has emerged. Go and wash your face, as a spring has erupted." Hazrat Khizer advised, "Go and bathe there. First take a bath there and go home. They will present you this bat. Distribute the bat to all therein. They should take from your part of the food. They, your co-workers in help (kiryar), have eaten their part of the food, and they have left your part to you. At the end, when you'll eat, the food will not finish. Then keep the small bowl aside and ask your brother to come and pull the beam. They will laugh at you. After touching/pulling the beam thrice, you ask your brother to hold the other side of the beam and pull."

Thus, he comes and takes a bath there where the spring has erupted. Afterwards he comes here in the house. His brother is surprised and says, "Oh! How quickly you returned?" He says, "I got the beam." He asks, "Where is that?" He replies, "Wait, it will come, a person will bring it." Then he comes and gives his part of the bat to him that has been left for him. Then he offers the bat in the small pot to everyone, and they laugh at him. Everyone takes from the food. The first person takes from the food, second takes, third takes, everyone turn-by-turn takes, but the food is not finished. Each one of them blames each other that you do not take fully from the food and they reply, "Oh dear! I have taken fully but the food fills in the bowl again." When all of them are finished with taking from the food, the food is not finished. They then say there must be some unknown secret.

Then he ascends onto the wall and asks his brother to come up. He asks, "What to do?" Khoja Big Ali tells his brother, "Let's pull the wood/beam." Khoja Maribor replies, "The people will laugh at you. Is it possible to pull wood?" Khoja Big Ali insists, "Okay, it doesn't matter if they laugh at us. But come on! Let's try." After touching the beam three times, Khoja Big Ali asks his brother to hold the other side of the beam. He holds the beam and Khoja Big Ali pulls. The beam thus stretches beyond the required limit. Then the people say, "Oh God! There must be something, some secrecy herein."

Khoja Maribor pulled it. Khoja Big Ali held it and he pulled it and it became long. Then when it stretched he had didor of Khizer at the spring, and Khizer said, "Don't stay there at the house you made, your place will be in Langar." The Langar of our Pamir. Then he said, "Your place will be there." He said, "True." Then he made the house and went to Langar.

After construction of the house, he goes to Langar. When he is in Langar, he goes to the top of a cliff (buq). There he constructs a mosque and offers prayer. Now his grave is also there. This brother has seen it. His house is there, downward. $\mathrm{He}$ 
then offers prayer there and his brother is also there. Behind his brother are two dogs, like a wolf, of course, wolves. They are still alive and sometimes they appear and both are white. He thus takes his prayer-mat ( jāy-e namazz) on the Panj River, puts it on the surface on the river and offers prayer. The Panj River has a huge amount of water that covers our riverbed during summer. His brother sees that he showed him his miracles. This Khoja Big Ali laid his pustek (prayer-rug of skin) on the surface of the river and offered prayer. He showed his miracle. There was ice there. He took that ice and broke it, and put it in the cave and he left the teakettle on it and the ice burned. It brought the tea to a boil. They showed each other their miracles, Khoja Big Ali and Khoja Maribor.

The miracles in Sost are made possible through the didor of Khizer. Khoja Big Ali and his brother are engaged in beneficial work when they realize that the beam for the house is too short. Faced with this difficulty, Khoja Big Ali departs to obtain more wood. Outside, he meets Khizer, the saint who can remove difficulties. ${ }^{23}$ Khizer, who is associated with water, causes a hot spring to emerge from the ground. This hot spring exists today in the Sost settlement area of Sarhadd-e Brughel. It is very helpful to the people there, providing warm water for bathing and washing clothes in the high-altitude settlement. Khizer advises Khoja Big Ali to wash in the water, and after doing so, Khoja Big Ali is imbued with barakat so that he performs several miracles: the food cannot be finished and is replenished, and he stretches the beam. A bowl that provides unending food is a well-known motif of South Asian and world oral tales (Aarne, 205-06; Thompson and Roberts, 85-86). The motif of stretching the roof beam, however, is a miracle attributed to several northwest Indian religious leaders: 'Abd al-Ghafur, the Ākhund of Swat, and Ram Singh, ${ }^{24}$ a Sikh leader from Firozpur (Temple, 325-26). ${ }^{25}$ Temple comments that "the same stories are told of all of... the religious leaders in the Punjab" and that "tales radiate from a few central stories which are probably very old." Temple's comments on multiple existence and variation, hallmarks of oral tales, indicate that Khoja Big Ali's stretching of the beam is acknowledged as a proof of miraculous powers and barakat that is recognized throughout not only the Pamir, but also the northwest region of South Asia. The story from Sarhadd-e

\footnotetext{
${ }^{23}$ See the discussion of the qadamgoh shrine of Khoja-e Khizer below for details about Khizer.

${ }^{24}$ Ram Singh is regarded by some as the 12th guru in the Sikh guru lineage, although the orthodox Sikh tradition closes the guru silsila (selsela) after the 10th guru, Gobind Singh (d. 1708), after which the Guru Granth Sahib becomes the final and eternal guru of Sikhs.

${ }_{25}$ Temple's brief article is based on a 24-page pamphlet by Rev. T.P. Hughes, "The Akhund of Swat, a Muhammadan Saint, and Dilawar Khan, the Converted Afghan Brigand," published in Calcutta by the Christian Intelligencer in 1876 .
} 
Brughel of Wakhan dips deep into the signifying well of oral narratives to tap a regional source for spiritual authority.

After performing miracles in Sost, Khoja Big Ali again encounters Hazrat Khizer who instructs him to move to Langar. There, he and his brother display miracles demonstrating control over the solid and liquid forms of water by burning ice and praying on top of the river. Khizer's barakat and his association with water enable the two brothers to perform their miracles involving ice and water. From a landscape perspective, Langar marks the extent of Wakhi settlement in Wakhan. In effect, it is the upper limit of Wakhi and hence Isma ili influence, a boundary whose existence is demonstrated by the custom of bringing the bodies of any Wakhi who die on the Pamir to Langar for burial in the ground made sacred by Khoja Big Ali. It is fitting that Khizer, who aids those traveling in the wilderness, instructed the two Khoja saints to go and occupy this remote and aptly named settlement. ${ }^{26}$ Located at the uppermost edge of the Wakhi and Isma ili area of Wakhan, Langar needed powerful saints to protect this border. Even today, the authority of Khoja Big Ali and the sanctity of his mazar are acknowledged and respected by all who travel through Langar. Moreover, his authority is maintained by the two white wolves mentioned in the narrative. A separate narrative underscores the power and authority of the saint. When outside people came to dig the mazar of Khoja Big Ali for artifacts, the two wolves appeared and attacked the would-be robbers, who were also pelted by stones piled at the grave. The power of the saint at his site is such that the site cannot be desecrated. In their daily lives, Wakhi people moving between the Pamir and the lower settlements stop here to offer prayer and seek the saint's blessing (Figure 5).

\section{Qadamgoh (Qadamgāh) Shrines}

At the west end of the village of Sast is the qadamgoh of Khoja-e Khizer (Khwāja-ye Khezr). Khizer, "the Green One," is a prophet made immortal by drinking the water of life. Although identified with the guide of Moses mentioned in the Koran, Khizer is closely associated with mystical Islam as a guide and aid for travelers, especially those in out-of-the-way places (Hodgson, 460-61; Omar, 286; Renard 2011; Wensinck 2011). Because Khizer appears to help those in need, his shrine in Wakhan is both oston - that is, a place where one can receive his blessing - and qadamgoh, where he appeared to

\footnotetext{
${ }^{26}$ Langar means a kitchen or rest-house where food is prepared for the poor or for travelers or pilgrims.
} 


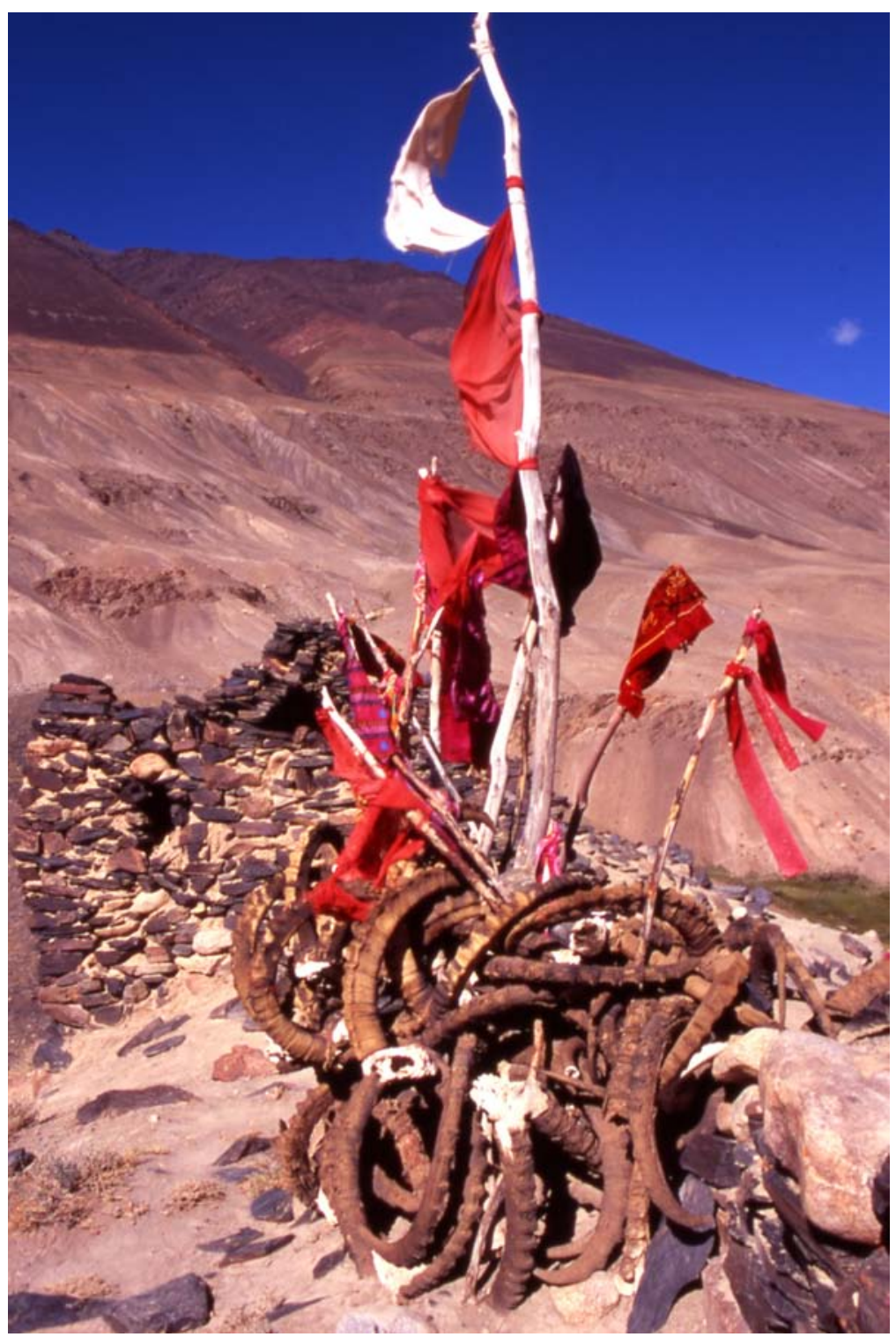

Fig. 5. Khoja Big Ali mazar at Langar 
guide or aid those in need. In Sast, the shrine is amid a grove of trees and is bounded by a low wall. The grove borders on barren land and is an appropriate location for a saint associated with vegetation and life.

An elder of the village described his own experience with the shrine:

Here is a qadamgoh of Hazrat Khoja-e Khizer. This is a very sensitive shrine. It is here on the lower side of the road, among the trees. Hazrat Khoja-e Khizer is alive. $\mathrm{He}$ is always alive in this world. He is always in movement. Khizer is alive in all places. The miracles are indicated, if you go with pure heart and ask of him, whatever it is, it is fulfilled. For example, if you go with clean mind and pure heart and wash your face and go on Friday night, whatever you request, it will come to you. For instance, when my brother passed away, I had no children. I went there and bowed my head and said, "I need nothing else in this world other than children because alone I cannot maintain my livelihood." So at present, he has bestowed upon me four sons. One is currently teacher in the school. And sir, my daughter is also in the school. I made a vow and went weeping to the court of Khoja-e Khizer and Almighty God and here I washed my face in the water at the shrine of Khoja-e Khizer Hayat (i.e. hayāt "life") and he fulfilled my intentions.

The color associated with Khizer is green and an epithet of his in Wakhan is Savz pushon (Pers. sabz-push), the green-clad one. Khizer has also been described as "a venerable man clad in white raiment" (Omar, 289; Nicholson, 13). This depiction resonates strongly with the image of the venerable man clad in white, well known throughout the Pamir-Hindukush region (Mock 1998, 76-77) (Figure 6).

The Isma ili communities in the Pamir and Hindukush regions, as has been noted, trace their origin to the eleventh-century Isma ili missionary, poet, and philosopher Nāser Khosrow (Iloliev 2008b, 63; Schadl, 71). He lived the last fifteen or twenty years of his life in the small village of Yomgān, deep in the Hindukush mountain region of what is today Badakhshān Province of Afghanistan (Hunsberger, 227). In Yomgān, Nāser found refuge and patronage under an Isma ili ruler, and a place to write. Most of his written works that we have today were completed in Yomgān. And it is in Yomgān, south of the town of Jorm on the road to the famous lapis lazuli mines at Sar-e sang and the Anjoman pass to the Panjshir Valley, that the tomb and shrine of Nāser Khosrow is located today (Dupree, 10-21; Schadl, 64).

Nāser's writings give no indication of how he may have carried out missionary activities in the region. Yet the wide dispersion of Isma ili traditions and the universal reverence for Nāser as a saint and as the chief proponent (pir-e qodus) of Pamir Isma ilism incontrovertibly demonstrates that his mission and teachings indeed spread from Yomgān throughout the region. 


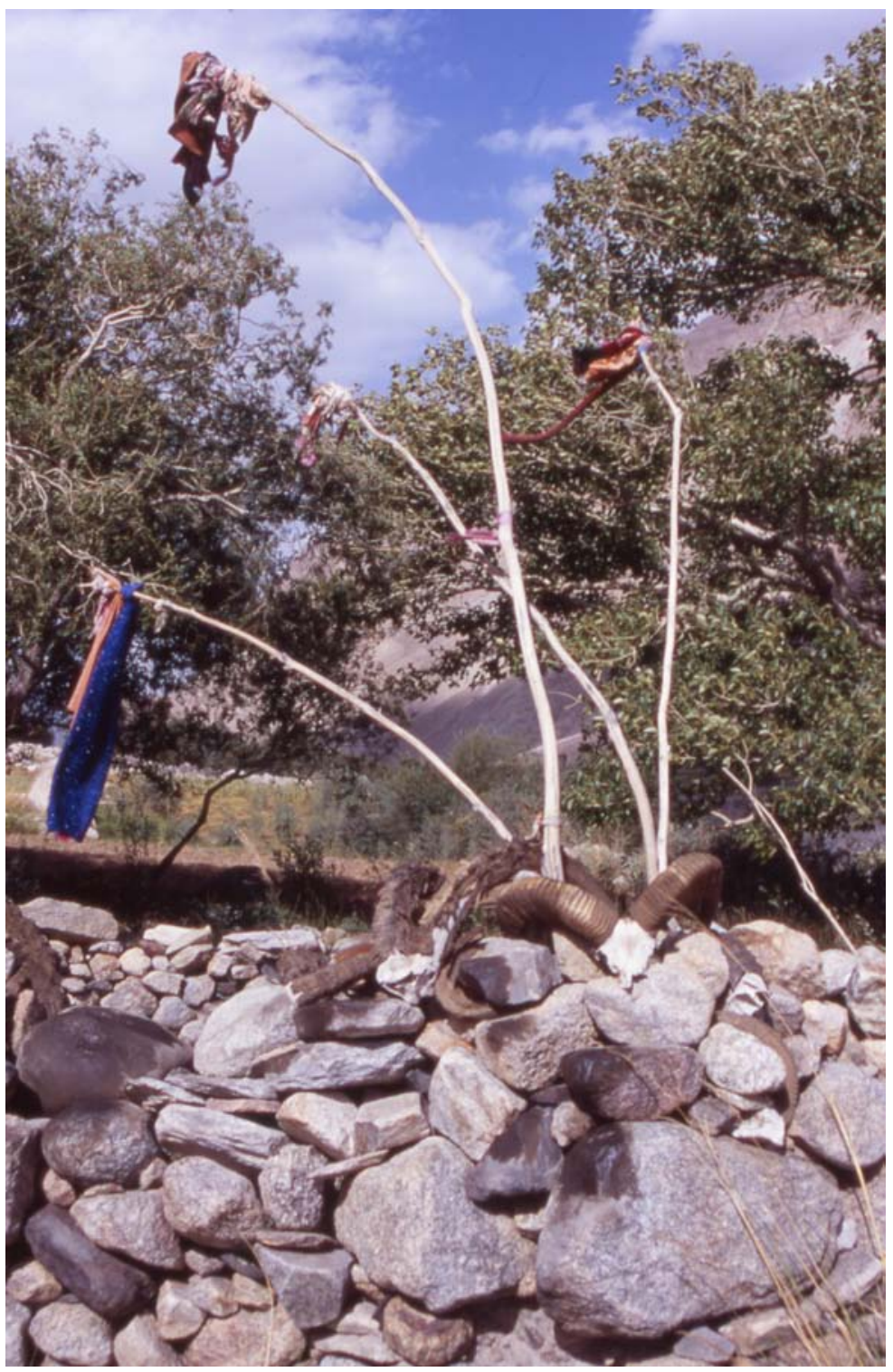

Fig. 6. Khoja-e Khizer qadamgoh at Sast 
Local tradition does describe Nāser's activities and places him in locations in the region. In the village of Yimit in Wakhan, there is today a shrine at the place where Nāser demonstrated several miracles and brought his message to the people. Yimit is located approximately four kilometers downstream from Khandut, the present district headquarters (Mock and O’Neil, Appendix 5). Nāser was the most important Muslim saint traveler, and his shrine is a highly significant exemplar of the shrine tradition of Wakhan and, by extension, of the Pamir-Hindukush region.

The Yimit $m u k h i^{27}$ voiced his concern about the vulnerability of the Nāser Khosrow shrine complex during an interview, recognizing its importance and the need to preserve it. Speaking on behalf of the Yimit Isma ili community, he expressed a desire to keep the shrine complex within the compound of the jamat khana, and asked for the author's help in notifying the Department of Jamati Insitutions ${ }^{28}$ that a compound should be built to preserve the site.

Like shrines in Tajikistan Wakhan, the Yimit shrine complex is visited both by individuals seeking the saint's barakat for personal reasons and by the community for annual observances. An annual observance takes place at the time of the Persian New Year (observed 16-18 March in Wakhan). The community marks the first day of the month of Aries (Hamal) as a day of celebration of Hazrat Pir Nosir Khusraw (i.e. Nāser Khosrow). In Wakhan, the exact day, called shohgun, is determined through observation of the sun in relation to a fixed point on the mountains above the village, as seen from a fixed point within the village. According to the Yimit mukhi, "When the sun comes between those two rock peaks on the mountain, on that day we start the new year. That is our shohgun." This observational system of calculating the agricultural calendar is used in other Wakhi villages in Tajikistan and Pakistan (Iloliev 2008a, 92).

In Yimit, villagers state that one person makes the observation and that the individual, called hamal-bin ("Aries-observer"), "should be pious, honest, elderly, and well-liked by the community." When the hamal-bin sees the sun touch the point on the mountain, he goes and informs each household to prepare themselves and put on clean clothes. Community members wash, put on clean clothes, cook special food, and one or two hours before dawn, assemble at the shrine of Nāser Khosrow for the ritual of Shohguni Nosiri Khusraw. The ritual is described thus:

${ }^{27}$ Mukhi is the guardian of the jamat khana.

28 The Department of Jamati Institutions at the Secretariat of His Highness the Aga Khan at Aiglemont in France is responsible for coordinating the activities and programs of the Isma ili community's institutions. 
We each carry a small wooden pot (pori) of flour and a large container (kubun) of bread (khech) and go there. People of all the clans go there, but the women are not allowed and outsiders are not allowed. The tradition is like this, if outsiders are allowed, for one week there would be a blizzard (zem dama). It would be cold. The community members gather, eat the food, offer prayers, and then they start throwing flour on each other. They catch each other and together throw flour at one another. We throw so much flour that the meadow becomes covered with flour.

Afterwards, the elders kiss each other's hands, then the gathering disperses and the people return to their houses and clean the smoke ( $d u d a)$ for the new year. They sweep their house and clean the smoke from winter fires. Then small pieces of wood are put under the roof in the house as an obstacle (shigard) which we call shohgun band, it is a custom in each house. Afterwards, we take out the seeds. Our shohgun and our work starts from this date. This is our tradition of our Nāser Khosrow. Yimit is famous for this. From there onward, the New Year becomes easy for the people.

Throughout Wakhan, people depend on Yimit for this ritual. From Putr to Sarhadd the people commence it. Until the sun reaches the specified place, we do not commence the ritual. We wait for our sunlight to reach that point. This tradition of Nāser Khosrow that is in our village, among all the Wakhi people, this is ours alone. This tradition arrived here in Yimit, and we have faith in it. We always calculate by this sun of Nāser Khosrow and we start our work accordingly. This custom comes from our elders, from our many generations.

The story of how this ritual is connected with Nāser Khosrow is also interesting. In brief, it goes like this: Nāser arrives in Yimit dressed as a wandering mystic (malang, dervish) in old clothes and carrying a wooden staff (osoy). There in Yimit, a wedding feast is taking place. Nāser enters the wedding house (tuy xona), but is rebuffed and abused, and the men in the wedding house throw stones and sand at him. One woman of the house, however, shows him respect and greets him kindly, and Nāser speaks kindly to her. He then leaves the wedding house and goes to a location at the edge of the village. There, he plants his staff in the ground and a grove of trees miraculously grows from the staff. Nāser then changes into regal clothes and mounts his white horse $($ duldul). He carries a sword (Wakhi xingar = Pers. khanjar) instead of a staff. He returns to the wedding house and is greeted with honor. The men offer him food but he refuses it, saying that when he came in rags, they would not offer him food, but now that he has come in robes, they offer him the tastiest delicacies. He then commands his sleeve (drest) and whip (qamchin) to eat the food. The food turns to stone on the spot. One "green stone" Nāser touches with his whip and it splits into two. On one side are "five deep finger (yangl) marks," which represent "the qualities of panj-tani." On the other side are seven holes (kulkul) that symbolize the haft hodud-e din (lit. "seven stages of religion," the seven steps in Isma ili hierarchy). Nāser then rebukes the 
people and, in some versions, he then brings down a flood on the people as punishment (Figure 7).

As Nāser is leaving the wedding house, the men ask him for guidance and for his blessing. He tells them that his blessing will remain with them if every year, from now until forever, they throw sand and stones at each other on the shohgun rawor, just as they threw sand and stones at him. The people agree, but later, however, substitute flour for the sand and stones. Today, everyone agrees that although Nāser's directive $(a m r)$ was for sand, people now throw flour at each other. ${ }^{29}$

At the site today, the food that Nāser turned into stone remains as a token of the miracle and is the focal point of veneration. The stone objects are displayed under a large willow tree inside a low-walled compound. (Figure 8)

This story of a visitor scorned because of his worn clothing and rough appearance occurs in the Safarnāma of Nāser Khosrow as the well-known episode of Nāser and his brother at the baths of Basra (Hunsberger, 205-08). Clad in old and coarse clothes, Nāser and his brother are denied entrance to the baths by the attendant. Children throw stones at them and chase them away. Nāser is able, however, to obtain decent clothing and he returns to the baths, where he is made welcome. The attendant is ashamed of his previous conduct and is apologetic.

The Yimit story seems an adaptation of this event from Nāser's travels and, as a conversion narrative, ${ }^{30}$ is emblematic of the acceptance of Nāser's message and teachings by the people of Yimit and Wakhan. The Basra bath episode from the Safarnama, interestingly, is written in Persian at the threshold to Nāser's tomb in Yomgān (Schadl, 85), indicating that it was highly significant to Pamiri Isma ili tradition. It seems reasonable to assume that the story circulated through the region and reached Yimit, though it is impossible to ascertain whether Nāser actually visited Yimit. Yimit is approximately a one-week journey on foot from Yomgān and it is, therefore, conceivable that Nāser might have visited the kingdom of Wakhan.

${ }^{29}$ For a current account of the Nauroz festival as observed in the Wakhi area of Hunza, which includes the shogun, the solar observations and the throwing of the flour, see "The Return of SEMN and Thagam Festival," in Pamir Times online at: http://pamirtimes.net/2008/03/07/thereturn-of-semn-and-thagam-festival/. Tibetan Losar (New Year) observances also include throwing tsampa (barley flour).

30 The essential equivalence of conversion narratives and founding legends or "legends of origin" in Central Asia, and the ethnogenic function of such discourse has been thoroughly described by DeWeese, especially pages 489-90. 


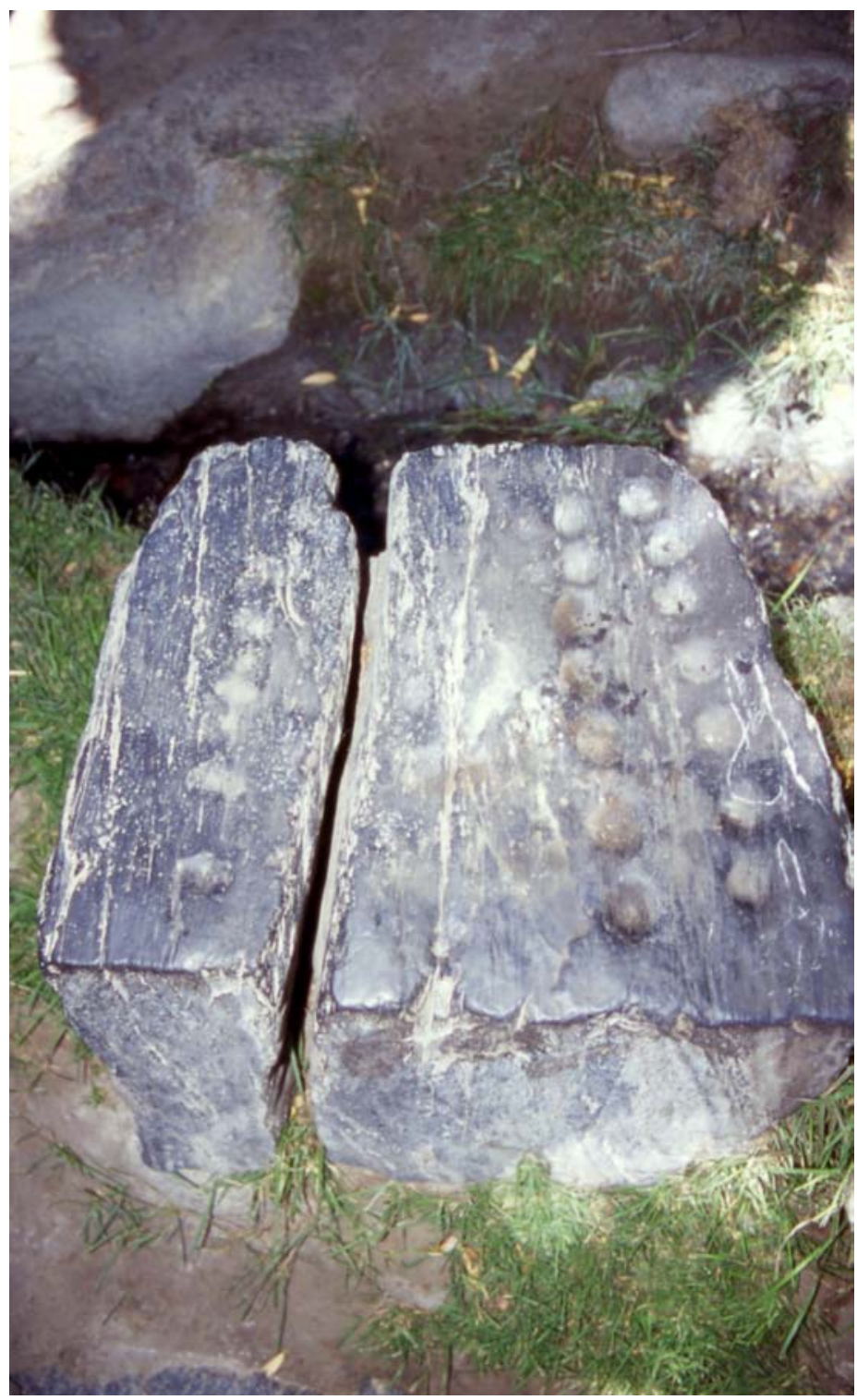

Fig. 7. Naser Khosrow miracle stone at Yimit 


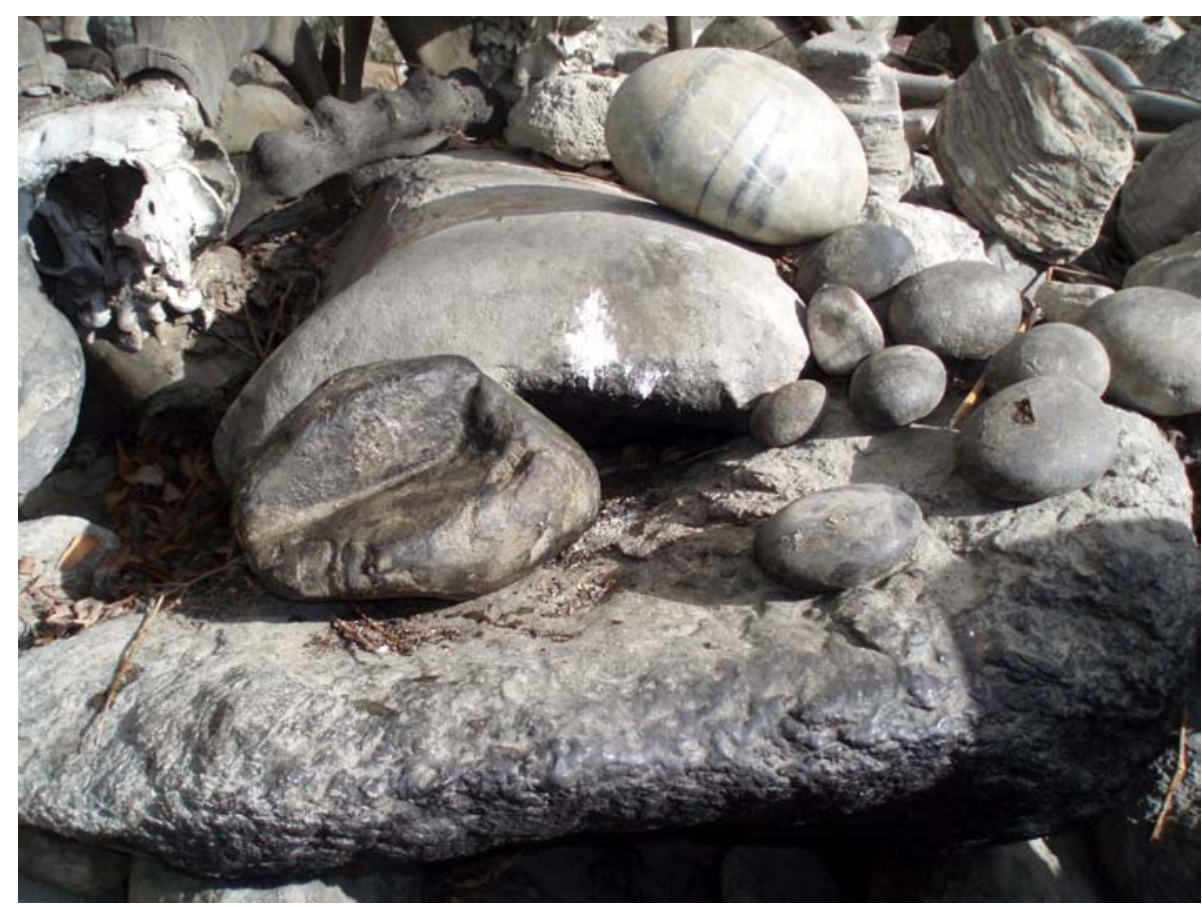

Fig. 8. Liver, kidney and heart of sheep turned to stone by Naser Khosrow at Yimit

Tradition does state that Nāser did not go beyond the Yimit-Khandut settlement, as this interview with a member of the Khandut Isma ili community indicates:

If he has gone up to Sarhadd and taken the Isma'ili da'vat, if he appeared in some empty place and if any error (ghalati) was made or not, it hasn't been written in any book and no historical record remains. Perhaps no mistake was made. In the Wakhan area, the only mistake (ghalati) occurred in Yimit, and then he said, "Yimit! Let the flood go and destroy the cruel settlement (zolm-ābād)."

With this mention of a flood as retribution for the sins of the villagers, the Wakhan oral narrative moves beyond the outlines of the story from Nāser's Safarnāma and begins to take on the structure of another famous regional narrative; the story of Kampir Diyor (Pers. Diār) "the old woman's village" in the Chapursan Valley, a Wakhi population area in Pakistan adjacent to Wakhan (Mock 1998, 319-22). The general shape of this widespread Karakoram legend is that an old man appears and is refused hospitality by all but an old woman. The white-bearded saint blesses the old woman and instructs her to 
leave her home for high ground. She does so and looks back to see the saint upon his white horse, bringing a devastating flood down upon the village that scorned him. Her winnowing basket is turned to stone and remains on the roof of her now-destroyed house as a token of the saint's power. Stories following this pattern are known from the Raskam Valley east of the Shimshal Pamir, the Shigar Valley of Baltistan, and the Darel Valley of Indus Kohistan (Mock 1998, 306). The existence of this story type in non-Isma ili settlement areas demonstrates that the story, even if its roots may be in Nāser's experience at the baths of Basra, is retold with a different significance. For example, all the valleys are prone to catastrophic glacial outburst floods, which could suggest a correlation between geophysical context and interpretive constructs of landscape.

\section{Conclusion}

Previous religious traditions preserved in places such as the oston at the Khandut jamat khana and in objects such as the Panja stone are now integrated into Islamic tradition. The power and significance of these objects and places, the narratives told about them, and the rituals connected with them are part of a shared understanding that shapes the identity of the people residing in the landscape. As long as people have resided there, it is likely that the sacred quality of the landscape and of particular outstanding objects in it have formed part of the sacred history of the region.

The legend of Nāser Khosrow's miracles in Yimit is the most fully developed and detailed of the shrine narratives, and incorporates sacred objects, rituals, and places. It serves as a powerful paradigm of identity for Isma ilis in Wakhan and in the Pamir-Hindukush region. The narrative itself has links to other narratives, including - through the image of the white-bearded saintthe widespread legends of Hazrat Khizer. The Khizer narrative also underlies the narrative of Khoja Big Ali and Khoja Maribor. The narratives together form a whole that is consistent and cohesive for the community. The legends of saints and shrines incorporate places, objects and motifs sacred in pre-existing traditions so that the saints and shrines have become part of the intrinsic system of beliefs and practices, a process also noted in the west Pamir, the Hunza Valley, and Central Asia (Dodykhudoeva, 151; Frembgen, 100; McChesney, 68).

Legends of saints are literally "God's truth," providing the interpretive lens through which communities represent their past and understand how they came to be who they are in the present. Such legends are the means by which 
the past is made intelligible and are unfailingly described by people as historical accounts. Legend and history are not separable categories from the perspective of those who tell these legends. ${ }^{31}$ It is our outside analytical perspective that problematizes their coherence and unity and views them as two separate categories. Through telling and hearing these legends, the community constitutes and validates an interpretation of the world as a place where miraculous events occur.

Such legends draw upon a commonly understood set of signifiers and follow a familiar discursive pattern: a set of topoi that recur throughout the region, analogous to shared bundles of linguistic isoglosses that define it as an ethno-linguistic region. On a more specific level, the legends are connected with sacred places known to all members of the community. In retelling these legends, community members recreate the landscape within which they live and revitalize the deeds of their saints and their ancestors in the landscape.

\section{References}

A. Aarne, The Types of the Folk Tale: A Classification and Bibliography, Helsinski, 1981.

G.J. Alder, British India's Northern Frontier, 1865-95: A Study in Imperial Policy, London, 1963.

H.W. Bailey, "Saka Studies: The Ancient Kingdom of Khotan," Journal of the British Institute of Persian Studies 8 (1970), pp. 65-72.

E. Bashir, "Khowar-Wakhi Contact Relationships," in D.W. Lönne and H. Nespital, eds., Tohfa-e Dil: Festschrift Helmut Nespital, Reinbek, 2001, pp. 3-17.

Idem, "Wakhi," in G.L. Windfuhr, ed., The Iranian Languages, London and New York, 2009, pp. 825-62.

C. Beckwith, The Tibetan Empire in Central Asia: A History of the Struggle for Great Power Among Tibetan, Turks, Arabs and Chinese During the Early Middle Ages, Princeton, 1987.

D. DeWeese, Islamization and Native Religion in the Golden Horde: Baba Tukles and Conversion to Islam in Historical and Epic Tradition, University Park, Penn., 1994.

L.R. Dodykhudoeva, "Ethno-cultural Heritage of the Peoples of West Pamir," Collegium Antropologium 28 (Supplement 1) (2004), pp. 147-59.

L. Dupree, "Saint Cults in Afghanistan," American Universities Field Staff Reports, South Asia Series 20, Hanover, New Hampshire, 1976, pp. 1-26.

D.I. Edelman and L.R. Dodykhudoeva, "The Pamir Languages," in G.L. Windfuhr, ed., The Iranian Languages, London, New York, 2009, pp. 773-86.

31 The word legend (from Latin legere "to read") derives from Medieval Latin legenda, which were exemplary accounts of saint's lives, to be read on that particular saint's appointed day. In folklore studies, legend refers to nonhistorical or nonverifiable narratives passed from generation to generation and popularly accepted as true. The problem of such "apparent irrationality in folklore" is one of appearances, i.e., of which interpretive lens we choose to apply. 
H. Emadi, "The End of Taqiyya: Reaffirming the Religious Identity of Isma'ilis in Shughnan, Badakhshan: Political Implications for Afghanistan," Middle Eastern Studies 34.3 (1998), pp. 103-20.

I.M. Franck and D.M. Brownstone, The Silk Road: A History, New York, 1986.

J.W. Frembgen, "Sayyid Shah Wali, Missionary and Miracle Worker: Notes on the Hagiography and Cult of a Muslim Saint of Nager and Hunza," Zeitschrift der Deutschen Morgenlandischen Gesellschaft 155.1 (2005), pp. 69-104.

R. Grousset, The Empire of the Steppes: A History of Central Asia, New Jersey, 1970.

H. Hauptmann, "Pre-Islamic Heritage in the Northern Areas of Pakistan" in S. Bianca, ed., Karakoram: Hidden Treasures in the Northern Areas of Pakistan, Turin, 2007, pp. 21-40.

M.G.S. Hodgson, The Venture of Islam: Conscience and History in a World Civilization: The Expansion of Islam in the Middle Periods, Chicago, 1974.

B. H. Hopkins, "Jihad on the Frontier: A History of Religious Revolt on the North-West Frontier, 1800-1947," History Compass 7.6 (2009), pp. 1459-69.

A.C. Hunsberger, Nasir Khusraw: The Ruby of Badakhshan: A Portrait of the Persian Poet, Traveller and Philosopher, London and New York, 2003.

A. Iloliev, The Isma'ili-Sufi Sage of Pamir: Mubarak-i Wakhani and the Esoteric Tradition of the Pamiri Muslims, Amherst, New York, 2008a.

Idem, "Popular Culture and Religious Metaphor: Saints and Shrines in Wakhan Region of Tajikistan," Central Asian Survey 27.1 (2008b), pp. 59-73.

V.A. Ivanov, A Guide to Ismaili Literature, London, 1933.

B. Litvinsky, "Copper Cauldrons from Gilgit and Central Asia: More about Saka and Dards and Related Problems," East and West 52 (2002), pp. 127-49.

R.D. McChesney, "Zamzam Water on a White Felt Carpet," in M. Gervers and W. Schlepp, eds., Religion, Customary Law, and Nomadic Technology, Toronto, 2000, pp. 63-80.

R. Middleton and H. Thomas, Tajikistan and the High Pamirs: A Companion and Guide, Hong Kong, 2008.

A. Miller, Tales from the Wakhan: Folklore and Archaeology of the Wakhan Corridor, Kabul, 2009.

V. Minorsky, Hudüd al-'Alam: The Regions of the World, 2nd ed., London, 1970; repr. Karachi 1980.

J. Mock, "The Discursive Construction of Reality in the Wakhi Community of Northern Pakistan," doctoral dissertation, Dept. of South and Southeast Asian Studies, Berkeley, University of California at Berkley, 1998.

Idem, unpublished field notes, 2007.

Idem, "The Red Buddha Hall Road Revisited: Recent Discoveries from Wakhan District, Afghanistan," 37th Annual Conference on South Asia, Madison, Wisconsin, 2008.

J. Mock and K. O’Neil, "Tourism Promotion in Wakhan District, Badakhshan, Afghanistan," Deutsche Gesellschaft fur Technische Zusammenarbeit (GTZ) for the Aga Khan Foundation, Kabul, 2005, p. 64.

G. Morgenstierne, Iranian Pamir Languages (Yidgha-Munji, Sanglechi-Ishkashmi and Wakhi), Oslo, 1938.

C.M. Naumann, "Ein Ehemaliges Wildyak-Vorkommen im Afghanischen Pamir," Bonner Zoologische Beitrage 24.3 (1973), pp. 249-52.

R.A. Nicholson, Studies in Islamic Mysticism, Cambridge, 1921.

I. Omar, "Khidr in the Islamic Tradition," The Muslim World 83.3-4 (1993), pp. 279-94.

J. Payne, "Pamir Languages," in R. Schmitt, ed., Compendium Linguarum Iranicarum, Wiesbaden, 1989, pp. 417-44.

Idem, "Tajikistan and the Tajiks," in G. Smith, ed., The Nationalities Question in the Post-Soviet States, London, 1996, pp. 367-84. 
M. Polo, The Book of Ser Marco Polo, the Venetian, Concerning the Kingdoms and Marvels of the East, tr. H. Yule, London, 1871.

J. Renard, s.v. "Khadir/Khiḍr," in J.D. McAuliffe, ed., Encyclopaedia of the Qur'än, Leiden, 2011.

M. Schadl, "The Shrine of Nasir Khusraw: Imprisoned Deep in the Valley of Yumgan," Muqarnas: An Annual of the Visual Cultures of the Islamic World 26 (2009), pp. 63-93.

P.O. Skjærvø, "Modern East Iranian Languages," in R. Schmitt, ed., Compendium Linguarum Iranicarum, Wiesbaden, 1989, pp. 370-83.

M.A. Stein, Ancient Khotan: Detailed Report of Archaeological Explorations in Chinese Turkestan, Oxford, 1907.

Idem, "A Chinese Expedition across the Pamirs and Hindukush, A.D. 747," The Geographical Journal 59.2 (1922), pp. 112-31.

Idem, Innermost Asia: Detailed Report of Explorations in Central Asia, Kan-su, and Eastern Iran Carried Out and Described Under the Orders of H.M. Indian Government, repr. New Delhi, 1981.

S.M. Stern, "The Early Isma'ili Missionaries in North-West Persia and in Khurasan and Transoxania," Bulletin of the School of Oriental and African Studies 23.1 (1960), pp. 56-90.

R.C. Temple, "Twice Told Tales of the Akhund of Swat," The Indian Antiquary 2 (1882), pp. 325-26.

S. Thompson and W.E. Roberts, Types of Indic Oral Tales: India, Pakistan, and Ceylon, Helsinki, 1991.

B. Tikkanen, "Some Areal Linguistic Isoglosses in the Transitional Zone Between Central and South Asia," in Israr-ud-Din, ed., Proceedings of the Third International Hindu Kush Cultural Conference, Karachi, 2008, pp. 250-62.

A.J. Wensinck, s.v. "al-Khadir," Encyclopaedia of Islam, 2nd ed.

S. Whitfield, ed., The Silk Road: Trade, Travel, War and Faith, Chicago, 2004.

A.N. Zelinksky, "Ancient Routes Through the Pamirs," Central Asian Review 13.1 (1965), pp. 44-54. 